\title{
Artificial symbioses of plants and microorganisms
}

Baymiev Al.Kh., Vershinina Z.R., Chubukova O.V., Matniyazov R.T., Baymiev An.Kh. Institute of biochemistry and genetics UFRC RAS, Ufa, Russia

$$
\text { E-mail: baymiev@mail.ru }
$$

Key message. The report discusses the problems of creating artificial associations of cultivated plants and rhizobia using plant and bacterial adhesins, as well as systems of controlled synthesis of growth-promoting substances by rhizospheric microorganisms.

Keywords: symbiosis, rhizobia, adhesins, nod genes

The creation of rhizosphere associations of cultivated plants with bacteria that stimulate plant growth and protect them from stresses of a biotic and abiotic nature is one of the most promising directions for the development of modern ecologically oriented agriculture. In this work, we consider the possibility of using plant and bacterial adhesins to create artificial associations of cultivated plants with rhizobia, in which the mechanism of activation of nod genes by root exudates is used for the controlled synthesis of growth-promoting substances. Using genetic engineering methods, we created various transgenic plants (tobacco, rapeseed, tomato, radish) expressed psl lectin gene of pea or rapAl adhesin gene of Rhizobium leguminosarum, and recombinant rhizobia strains containing gfp/gus marker genes under the control of Rhizobium leguminosarum nodABC promoter. On tobacco, tomato, and rapeseed plants, transgenic for psl and rapAl genes, showed the selectivity of colonization of their rhizosphere by $R$. leguminosarum bacteria in competition with natural soil microflora. Using rhizobia strains expressing the RFP fluorescent protein gene, a significant increase in the number of bacteria adhered to the roots of transgenic plants was shown compared with the control, which was preserved after a month of cultivation in the soil. It was shown that in recombinant rhizobia strains transformed with plasmids carrying the activation system for the synthesis of nod genes "nodD gene + nod promoter ABC + gfp/gus", the synthesis is activated and the products of marker genes are accumulated when treated with root exudates of host plants.

The strategy of inducible incorporation of target genes of PGPR microorganisms in the plant rhizosphere, with an experimental approach to constructing an "artificial rhizosphere" of nonsimbirophic plants, selectively and competitively colonized by nodule bacteria, can be successfully used to create stable and effective associations of nonsimbirophic economically beneficial plants with microorganisms with increased and included growth-promoting activity.

This research was supported by the Russian Foundation for Basic Research (project18-34-20004 mol_a_ved).

\section{Искусственные симбиозы растений и микроорганизмов}

Баймиев Ал.Х., Вериинина З.Р., Чубукова О.В., Матниязов Р.Т., Баймиев Ан.Х.

Институт биохимии и генетики - обособленное структурное подразделение Федерального государственного бюджетного научного учреждения Уфимского федерального исследовательского центра Российской академии наук, Уфа, Россия

Аннотация. Обсуждаются проблемы создания искусственных ассоциаций культурных растений и ризобий с
применением растительных $u$ бактериальных адгезинов, a также системь регулируемого синтеза ростостимулирующих веществ ризосферными микроорганизмами.

Ключевые слова: симбиоз, ризобии, адгезинь, под-гены

Создание ризосферных ассоциаций культурных растений с бактериями, стимулирующими рост растений и защищающими их от стрессов биотической и абиотической природы, является одним из наиболее перспективных направлений на пути развития современного экологически ориентированного сельского хозяйства. В представленной работе рассматривается возможность использования растительных и бактериальных адгезинов для создания искусственных ассоциаций культурными растений с ризобиями, в которых механизм активации nod-генов корневыми экссудатами используется для регулируемого синтеза ростостимулирующих веществ. Методами генной инженерии были получены линии различных культурных растений (табак, рапс, томат, редька) трансгенных по генам psl лектина гороха и rapAl адгезина Rhizobium leguminosarum, а также рекомбинантные штаммы ризобий, содержащие маркерные гены gfp и gus под управлением промотора nodABC Rhizobium leguminosarum. На трансгенных по генам psl и rapAl растениях табака, томата и рапса показана избирательность колонизации их ризосферы бактериями $R$. leguminosarum в условиях конкуренции с естественной микрофлорой почвы. С использованием штаммов ризобий, экспрессирующих ген флуоресцентного белка RFP, показано значительное увеличение количества бактерий адгезировавшихся на корнях трансгенных растений по сравнению с контрольными, которое сохранялось и через месяц выращивания в почве. Показано, что в рекомбинантных штаммах ризобий, трансформированных плазмидами, несущими систему активации синтеза nod-генов «ген nodD + промотор nod $A B C+\operatorname{gfp} / g u s »$ происходит включение синтеза и накопление продуктов маркерных генов при обработке корневыми экссудатами растений-хозяев.

Стратегия индуцируемого включения целевых генов PGPR-микроорганизмов в ризосфере растений вкупе с экспериментальным подходом к конструированию «искусственной ризосферы» несимбиотрофных растений, избирательно и конкурентоспособно колонизируемой клубеньковыми бактериями, может быть с успехом использована для создания стабильных и эффективных ассоциаций несимбиотрофных хозяйственно-полезных растений с микроорганизмами, обладающими повышенной и включаемой ростостимулирующей активностью.

Работа выполнена при поддержке гранта РФФИ 18-34-20004 мол_а_вед «Ризосферные микроорганизмы с регулируемым синтезом ростостимулирующих веществ». 